\title{
Physico-Chemical and Microbiological Characteristics of Gundpak- A Traditional Milk Product of Nepal
}

\author{
Pushpa Prasad Acharya ${ }^{1}$, Ganga Prasad Kharel ${ }^{2} \&$ Ramakrishna Chetana $^{3}$ \\ ${ }^{1}$ Central Department of Food Technology, Tribhuvan University, Dharan, Nepal \\ ${ }^{2}$ Central Department of Biotechnology, Tribhuvan University, Kirtipur, Nepal \\ 3 Lipid Science \& Traditional Foods Department, Central Food Technological Research Institute, \\ Mysore-570020, India \\ Correspondence: Pushpa Prasad Acharya, Central Department of Food Technology, Tribhuvan University, \\ Dharan, Nepal. E-mail: acharya2018@gmail.com
}

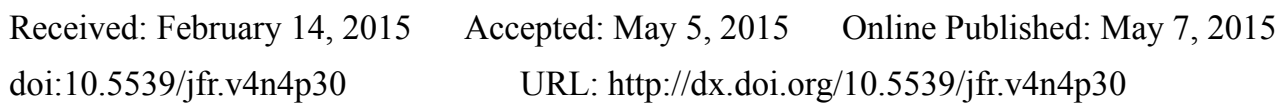

\begin{abstract}
Gundpak, is a popular khoa based traditional milk product of Nepal and commonly used as a sweet delicious food. Twelve market samples of gundpak were collected from the different areas of Kathmandu valley. The physico-chemical, sensory and microbiological analyses of the samples were investigated. The commercial samples were not consistent in their chemical compositions. The moisture, fat, protein, carbohydrates and ash were varied from 10.1 to $21.2,10.6$ to $16.5,16.8$ to $30.3,29.0$ to $54.8,2.4$ to 3.7 percentages, respectively. The microbiological analysis showed that Total Plate Count, Yeast and Mold, and Coliforms were varied from 0 to 5 $\times 10^{4}, 0$ to $8.0 \times 10^{3}, 0-1.1 \times 10^{2}$, whereas there was no growth of Staphylococci. The hardness, cohesiveness, gumminess, springiness, chewiness and adhesiveness values were varied from 31.7 to $245.3 \mathrm{~N}, 90.03$ to 296.3 , 7.84 to $22.06 \mathrm{~N}, 2.36$ to $7.62,1.45$ to $16.2 \mathrm{~N} . \mathrm{mm}$, and 0.3 to $6.8 \mathrm{mNm}$, respectively, among the samples. In the commercial samples, colour parameter, $L^{*}$ values was varied from 17.12 to 42.08 , indicating wide variations in appearance from light to dark brown. The overall sensory quality did not show significant variations. The minerals, calcium, magnesium, sodium, potassium, iron, zinc and copper were in the ranges from 390.7-527.15, 25.56-40.43, 188.86-215.93, 282.0-378.0, 0.41-0.52, 1.31-2.58 and 0.11-0.16 mg/100 g samples, respectively. These results indicated that Nepalese gundpak significantly vary in physico-chemical characteristics and hence require optimization of product ingredients and processing technology to get uniform high quality.
\end{abstract}

Keywords: colour values, $k$ hoa based sweet, nutritional values, sensory quality, texture profiles

\section{Introduction}

Milk based traditional sweet products contribute the dominant share in the food market of Nepal, popular among are: gundpak, khoa, sikarni, tar, pustakari, kalakand (Aneja et al., 2002). In India also, there are similar traditional sweet milk products such as khoa, lalmohan, peda, burfi, kalakand, basundi, rabri, kalam, kunda (Nawajeevan, 2005). Among these khoa (Thakur et al., 1991) rasogolla, lalmohan, peda, burfi, kalakand are native products of Nepal as well. These are produced by some organized dairies and Halwai (sweet maker) shops. 'gundpak' and pustakari are khoa based milk sweets prepared locally at a cottage scale in Kathmandu valley especially by Newar community. There is no mechanized production of these products till now. People within the country or outsiders who visit the Kathmandu valley buy 'gundpak' and 'pustakari' as a memento or bequest for their family, friends or neighbors. Gundpak is a protein-energy rich delicious and nutritious sweet milk product. The demand of the product is increasing throughout the country as well as outside day by day. The total production of gundpak in Kathmandu valley in the fiscal year 2010 was approx. 579.1 MT, worth of NRs. 192.5 million (Acharya, 2011).

As a sweet product, gundpak is highly esteemed by Nepalese consumer and kept in high priority from the time immemorial. Nepalese methai (traditional sweets) have been developed to preserve the nutritional quality of milk and to extend its shelf-life at ambient temperature. Milk based sweets are mainly prepared from two intermediate product bases: khoa (a heat-desiccated milk product) and channa (coagulated milk after draining of whey). In small and large cities, the processing of sweets is carried out on a small-scale by the Halwais (Indian 
sweet makers) cooks who have migrated from India.

However, gundpak production and sold in the local market vary widely in appearance, texture, composition and nutritional quality. Being a traditional product, there is neither specific recipe nor processing conditions for its production. The selection of ingredients and production process vary from place to place and from one manufacturer to another (Acharya, 2008). The product has no promulgated standard by the authorized government body yet. The objective of the present study is to find out the proximate compositions, texture profile, colour, nutritional and microbiological quality of the commercial gundpak, which might form the foundation for its optimization for uniform quality products. The research work also insists government body to formulate standards and enforced it to make uniform compositions product.

\section{Materials and Methods}

\subsection{Sample Collection}

The samples of gundpak were collected from the different production areas of Kathmandu valley in April, 2012. One kilogram of sample was collected from each producers and/or sellers in ice-box and immediately vacuum packed. Then, the sample was packed in air tight box and transported in a thermo-cool box by placing the frozen bio-cool packet in between the sample packet and deep frozen $\left(-10^{\circ} \mathrm{C}\right)$. After one day, the analyses were carried out.

\subsection{Physico-Chemical, Microbiological and Sensory Analyses}

\subsubsection{Proximate Analysis}

The moisture, fat, protein, total carbohydrate and minerals content of the samples were determined as per the procedures given in AOAC (2005).

\subsubsection{Microbiological Evaluation}

The microbiological analyses such as total plate count, Coliforms, Staphylococci and yeast and molds, were carried out according to the procedure given in APHA, 2001.

\subsubsection{Colour Measurement}

Colour of products was measured using the CIELAB illuminant $\mathrm{D}_{65}$ and $2^{\circ}$ view angle condition (Perez Magarino \& Gonzalez-Sanjose, 1999). The parameters $L^{*}, a^{*}, b^{*}$ and the total color difference $\left(\Delta \mathrm{E}^{*}\right)$ were measured in triplicates with a hunter lab color meter (Model, Labscan XE, USA) using the principle of reflectance of light in the wavelength range 400 and $700 \mathrm{~nm}$. The CIELAB parameter $\mathrm{L}^{*}$ indicates the lightness (or brightness), $\mathrm{a}^{*}$ indicates redness with positive values and greenness with negative values and $\mathrm{b}^{*}$ indicates yellowness with positive values and blueness with negative values. The parameter $\Delta \mathrm{E}^{*}$ indicates the total difference of colour with respect to a standard white. This system allows instrumental readings closely matching to the perception of human eye. The area of view was $1 \mathrm{inch}$ and pore size was $1.2 \mathrm{inch}$. The sample of $17 \mathrm{~mm}$ thick and $46 \mathrm{~mm}$ dia. was placed in small clean Petri plates over the aperture while analyzing the color.

\subsubsection{Texture Measurement}

The frozen commercial samples were equilibrated at room temperature $\left(25^{\circ} \mathrm{C}\right)$. The texture profiles of samples was measured by making uniform size sample with a circular diameter $(46 \mathrm{~mm})$ and height $(19 \mathrm{~mm})$ with a stainless steel ring and average weight was $40 \pm 2 \mathrm{~g}$ per piece of the sample. The hardness of samples was measured by an Instron Universal Texture Testing machine (Model LR5K, Llyods Instruments, UK). The product was compressed by $50 \%$ in two bites. The load cell of $5 \mathrm{KN}$ at a cross head speed of $100 \mathrm{~mm} / \mathrm{min}$ was used and the force of $1 \mathrm{KN}$ was applied for compression of the samples. Various Instron texture profile parameters were worked out from the force-distance curve as described by Bourne (1978).

\subsubsection{Sensory Analysis}

Twelve trained panelist from the Research Institute participated for sensory evaluation throughout the study. Representative samples of gundpak were presented to the panelists for discussion of the sensory attributes of the product. The definitions of the attributes were also discussed to get consensus. Descriptors were developed by asking the panelists to describe the product with the suitable descriptive terms. The common descriptors chosen more than $1 / 3$ of the panelists were used for the development of a scorecard, which consisted of each attribute on a $15 \mathrm{~cm}$ linear scale unstructured anchoring scale in which $1.25 \mathrm{~cm}$ was considered low and $13.75 \mathrm{~cm}$ was considered high (Stone et al., 1974). The score card was explained during the first training session. Judges were asked to practice scoring on the score card by sorting the samples according to the definition of each attribute. 


\subsubsection{Statistical Analysis}

The statistical analysis of data obtained in the experiments were analyzed by Ducan's Multiple Range Test (Ducan, 1955).

\section{Results and Discussion}

\subsection{Proximate Composition}

In commercial gundpak samples the moisture, protein, fat, carbohydrate and ash were ranged from 10.1 to 21.2 , 11.4 to $16.5,16.8$ to $30.3,29.0$ to 54.8 and 2.3 to 3.6 percentages, respectively, showing significant variations among the samples (Table 1).

Table 1. Proximate composition of commercial samples of gundpak

\begin{tabular}{|c|c|c|c|c|c|}
\hline Sample & Moisture (\%) & Protein $(\%)$ & Fat (\%) & Carbohydrate (\%) & Ash (\%) \\
\hline A & $14.8^{\mathrm{c}} \pm 0.29$ & $15.0^{\mathrm{d}} \pm 0.53$ & $20.4^{\mathrm{bc}} \pm 0.75$ & $46.7^{\mathrm{ef}} \pm 0.61$ & $3.2^{\mathrm{d}} \pm 0.03$ \\
\hline B & $12.0^{\mathrm{b}} \pm 0.54$ & $14.0^{c} \pm 0.56$ & $16.8^{\mathrm{a}} \pm 0.11$ & $54.8^{\mathrm{g}} \pm 1.07$ & $2.4^{\mathrm{a}} \pm 0.07$ \\
\hline $\mathrm{C}$ & $15.7^{\mathrm{d}} \pm 0.43$ & $10.6^{\mathrm{a}} \pm 0.24$ & $23.2^{\mathrm{d}} \pm 0.33$ & $47.9^{\mathrm{f}} \pm 0.84$ & $2.6^{\mathrm{b}} \pm 0.06$ \\
\hline $\mathrm{D}$ & $18.0^{\mathrm{f}} \pm 0.51$ & $14.0^{c} \pm 0.31$ & $22.8^{\mathrm{cd}} \pm 0.25$ & $42.6^{\mathrm{d}} \pm 0.51$ & $2.6^{\mathrm{b}} \pm 0.01$ \\
\hline E & $10.1^{\mathrm{a}} \pm 0.92$ & $11.4^{\mathrm{ab}} \pm 0.39$ & $23.4^{\mathrm{d}} \pm 0.37$ & $52.8^{\mathrm{g}} \pm 4.07$ & $2.3^{\mathrm{a}} \pm 0.10$ \\
\hline $\mathrm{F}$ & $21.2^{\mathrm{h}} \pm 0.50$ & $16.5^{\mathrm{f}} \pm 0.16$ & $30.2^{\mathrm{f}} \pm 0.44$ & $29.0^{\mathrm{a}} \pm 1.08$ & $3.1^{\mathrm{d}} \pm 0.05$ \\
\hline G & $20.5^{\mathrm{h}} \pm 0.96$ & $15.4^{\mathrm{de}} \pm 0.31$ & $21.7^{\mathrm{bcd}} \pm 0.20$ & $38.8^{\mathrm{c}} \pm 1.15$ & $3.6^{\mathrm{e}} \pm 0.05$ \\
\hline $\mathrm{H}$ & $19.4^{\mathrm{g}} \pm 0.27$ & $13.5^{\mathrm{c}} \pm 0.71$ & $19.5^{\mathrm{b}} \pm 0.19$ & $44.7^{\mathrm{de}} \pm 0.97$ & $2.8^{\mathrm{c}} \pm 0.16$ \\
\hline I & $11.6^{\mathrm{b}} \pm 0.24$ & $16.1^{\mathrm{ef}} \pm 1.18$ & $24.3^{\mathrm{d}} \pm 0.40$ & $44.8^{\mathrm{de}^{2}} \pm 1.02$ & $3.2^{\mathrm{d}} \pm 0.17$ \\
\hline $\mathrm{J}$ & $16.6^{\mathrm{e}} \pm 0.08$ & $16.0^{\mathrm{ef}} \pm 0.63$ & $21.3^{\mathrm{bcd}} \pm 0.20$ & $42.9^{\mathrm{d}} \pm 0.76$ & $3.2^{\mathrm{d}} \pm 0.03$ \\
\hline K & $18.4^{\mathrm{f}} \pm 0.20$ & $15.4^{\mathrm{ef}} \pm 0.24$ & $30.3^{\mathrm{f}} \pm 0.39$ & $32.8^{\mathrm{b}} \pm 0.13$ & $3.2^{\mathrm{d}} \pm 0.01$ \\
\hline $\mathrm{L}$ & $17.1^{\mathrm{e}} \pm 0.08$ & $11.8^{\mathrm{ab}} \pm 0.30$ & $20.4^{\mathrm{bc}} \pm 0.60$ & $47.1^{\mathrm{ef}} \pm 0.67$ & $3.6^{\mathrm{e}} \pm 0.07$ \\
\hline Average & 16.3 & 11.4 & 22.9 & 43.7 & 3 \\
\hline Maximum & 21.2 & 16.5 & 30.3 & 54.8 & 3.7 \\
\hline Minimum & 10.1 & 10.6 & 16.8 & 29 & 2.3 \\
\hline
\end{tabular}

Values are the mean of three replicates. Values $\pm S D$. Values having same superscript in a column did not differ significantly $(p>0.05)$ by $L S D$.

The average values for moisture, protein, fat, carbohydrate and ash were found out to be 16.3, 11.4, 22.9, 43.7, and 3.0, percentages, respectively.

The chemical compositions such as fat, protein, sucrose, ash, minerals etc. of some of the commercial milk products like khoa, burfi, gulabjamun and peda (Sharma, 1978), rabri were showed wide variations (Chatarjee, 1994). Chemical characteristics of the products generally depends on the nature of ingredients/constituents, quality of the raw materials and the extent of heat treatment during processing. Ray et al. (2002) studied the market and laboratory samples of peda and observed the variations in chemical and microbiological qualities.

\subsection{Microbiological Quality of Commercial Gundpak}

The microbiological quality of commercial gundpak samples is presented in the Table 2. According to the Bureau of Indian Standards (BIS, 1988), Indian traditional milk product burfi, which is similar to gundpak, has a standard plate count and yeast \& mold count should not exceed from $3 \times 10^{4}$ and 10 per gram of sample, respectively. All the commercial samples except sample A are within the limit in terms of standard plate count, whereas yeast and molds from samples $\mathrm{E}$ to $\mathrm{L}$ were found beyond the standard (Table 2). In terms of yeast and molds these samples can be considered as very poor quality. However, samples A to D showed no growth of yeast and molds. The exposing the product in open container might be the reason for the high counts of yeast and mold. In all samples, Staphylococci and Coliforms did not grow but coliform in sample A was counted high. This is the sign of un-hygienic conditions of the production area. The microbiologically safe product can only be 
produced if the production place is hygienic and product is packaged immediately after production and follow the good manufacturing practices (GMP).

Table 2. Microbiological quality of commercial samples of gundpak

\begin{tabular}{lllll}
\hline Sample code & Total bacterial count & Staphylococci & Coliform & Yeast and mold \\
\hline A & $5 \times 10^{4} \pm 1 \times 10^{4}$ & nil & $1.1 \times 10^{2} \pm 1.4 \times 10^{1}$ & nil \\
B & nil & nil & nil & nil \\
C & nil & nil & nil & nil \\
D & nil & nil & nil & nil \\
E & $7 \times 10^{2} \pm 1 \times 10^{2}$ & nil & nil & $8 \times 10^{3} \pm 2 \times 10^{2}$ \\
F & $8.33 \times 10^{2} \pm 1.5 \times 10^{2}$ & nil & nil & $2.3 \times 10^{3} \pm 58$ \\
G & $11.67 \times 10^{3} \pm 1.5 \times 10^{2}$ & nil & nil & $2.3 \times 10^{3} \pm 5.8 \times 10^{2}$ \\
H & $3.3 \times 10^{3} \pm 5.8 \times 10^{2}$ & nil & nil & $13 \pm 6$ \\
I & $1.8 \times 10^{4} \pm 2 \times 10^{3}$ & nil & nil & $23 \pm 6$ \\
J & $2.3 \times 10^{3} \pm 5.8 \times 10^{2}$ & nil & nil & $27 \pm 6$ \\
K & $1.67 \times 10^{3} \pm 5.8 \times 10^{2}$ & nil & nil & $27 \pm 6$ \\
L & $2.67 \times 10^{3} \pm 5.8 \times 10^{2}$ & nil & nil & $2.7 \times 10^{2} \pm 58$ \\
\hline
\end{tabular}

Values are the mean of three replications. Values $\pm S D$.

The samples, B, C and D were showed no growth in their respective media. There was no growth of Staphylococci in all samples. There was no growth of Coliforms except sample A $\left(1.1 \times 10^{2} \mathrm{CFU} / \mathrm{g}\right)$. It might be due to post-process contamination from un-hygienic production place and handling. In most of the samples there was no growth of Staphylococci and Coliforms and in some samples no growth of total plate count and yeast \& molds. This might be due to high sugar content as well as high temperature $\left(105-107^{\circ} \mathrm{C}\right)$ of cooking to the final product. The total bacterial count, coliforms and yeast and mold count ( $\mathrm{cfu} / \mathrm{g}$ ) were 0 to $5 \times 10^{4}, 0-1.1 \times 10^{2}$ and 0 to $8 \times 10^{3}$, respectively. Dwarakanath (1977), studied microbiological quality of the traditional Indian sweetmeats found that the varying number in all the different samples and reported that the coliforms were contaminated in fresh peda and burfi and Staphylococci and Salmonella in stored peda and burfi. Sharma and Joshi (1992), studied the bacteriological quality of milk products, burfi, khoa, which are basically similar to the gundpak, did not found the growth of the pathogenic organisms, Salmonellae and E. coli (Dharayia et al., 2010). Microbiological quality of the market sample A was found poor. It has been reported that the market kalakand sample contains total plate counts, coliforms and yeast and molds ranging from $29.5 \times 10^{3}, 6.6 \times 10^{2}$ to $15 \times 10^{2}$ and $4.4 \times 10^{2} \mathrm{cfu} / \mathrm{g}$, whereas laboratory samples had $1 \times 10^{3}, 40$ and $10 \mathrm{cfu} / \mathrm{g}$, respectively (Suresh, 1994). In comparison to some milk sweets, the product gundpak seems to be better quality in respect to microbiological quality.

\subsection{Color Measurement}

Color is one of the major attributes in assessing quality of any kind of food. Color can affect the overall perception on the worth of food from both an aesthetic and a safety point of view. It also the taste thresholds, flavor identification, food preference, pleasantness, acceptability and ultimately food choice (Clydesdale, 1984).

The $L^{*}$ value in commercial samples was varied from 17.12 to 42.08 ; indicating wide variations in appearance from lightest to dark brown. Most of the samples were significantly $(\mathrm{p}<0.05)$ different to each other except A, $\mathrm{B}, \mathrm{K}$ in terms of their lightness. The DE value of one sample $\mathrm{H}$ is lower (57.28), designates marginal dullness, whereas it was highest (75.53) for product code $\mathrm{L}$. The $\mathrm{a}^{*}$ value represents the redness/greenness of the samples. The sample L showed less $\mathrm{a}^{*}(3.51)$, whereas sample B showed more (8.91) redness/greenness. However, significant differences in $\mathrm{a}^{*}$ were observed among the samples. The sample $\mathrm{H}$ had high (25.41) $\mathrm{b}^{*}$ value indicating more yellowish tint, whereas it was very low (7.25) in L sample indicating less yellowish tint (Table $3)$. 
Table 3. CIE color measurement of commercial samples of gundpak

\begin{tabular}{lllll}
\hline Sample code & $\mathrm{L}^{*}$ & $\mathrm{a}^{*}$ & $\mathrm{~b}^{*}$ & $\Delta \mathrm{E}$ \\
\hline A & $32.2^{\mathrm{e}} \pm 0.56$ & $7.21^{\mathrm{a}} \pm 0.29$ & $15.16^{\mathrm{c}} \pm 0.51$ & $64.65^{\mathrm{i}} \pm 0.44$ \\
B & $32.28^{\mathrm{e}} \pm 0.76$ & $8.91^{\mathrm{e}} \pm 0.10$ & $18.26^{\mathrm{d}} \pm 0.52$ & $64.91^{\text {ef }^{\mathrm{e}} \pm 0.61}$ \\
C & $25.74^{\mathrm{b}} \pm 1.54$ & $8.52^{\mathrm{e}} \pm 0.32$ & $15.42^{\mathrm{c}} \pm 1.13$ & $69.78^{\mathrm{d}^{\mathrm{a}} \pm 1.12}$ \\
D & $30.69^{\mathrm{d}} \pm 0.47$ & $6.15^{\mathrm{c}} \pm 0.13$ & $16.64^{\mathrm{c}} \pm 1.25$ & $65.88^{\mathrm{g}} \pm 0.44$ \\
E & $30.32^{\mathrm{d}} \pm 0.33$ & $6.72^{\mathrm{bc}} \pm 0.16$ & $10.83^{\mathrm{b}} \pm 0.58$ & $65.93^{\mathrm{a}} \pm 0.24$ \\
F & $39.91^{\mathrm{h}} \pm 0.43$ & $8.84^{\mathrm{d}} \pm 0.75$ & $23.86^{\mathrm{g}} \pm 0.81$ & $59.15^{\mathrm{c}} \pm 0.30$ \\
G & $38.21^{\mathrm{g}} \pm 0.73$ & $7.30^{\mathrm{f}} \pm 0.32$ & $21.01^{\mathrm{f}} \pm 1.17$ & $60.16^{\mathrm{b}} \pm 0.58$ \\
H & $42.08^{\mathrm{i}} \pm 0.10$ & $6.44^{\mathrm{c}} \pm 0.03$ & $25.41^{\mathrm{h}} \pm 0.37$ & $57.28^{\mathrm{f}} \pm 0.05$ \\
I & $27.28^{\mathrm{c}} \pm 0.27$ & $6.68^{\mathrm{b}} \pm 0.47$ & $11.78^{\mathrm{b}} \pm 1.36$ & $68.35^{\mathrm{f}} \pm 0.28$ \\
$\mathrm{~J}$ & $34.00^{\mathrm{f}} \pm 1.80$ & $8.58^{\mathrm{ef}} \pm 0.67$ & $20.78^{\mathrm{ef}} \pm 1.92$ & $63.89^{\mathrm{h}} \pm 1.52$ \\
K & $31.72^{\mathrm{de}} \pm 1.27$ & $8.13^{\mathrm{f}} \pm 0.48$ & $19.22^{\mathrm{de}} \pm 2.48$ & $65.35^{\mathrm{e}} \pm 1.08$ \\
L & $17.12^{\mathrm{a}} \pm 0.85$ & $3.51^{\mathrm{d}} \pm 0.66$ & $7.25^{\mathrm{a}} \pm 1.82$ & $75.53^{\mathrm{e}} \pm 0.62$
\end{tabular}

Values are the mean of four replication. Values $\pm S D$. Values having same superscript in the column did not differ significantly $(p>0.05)$.

\subsection{Texture Profile Analysis}

The hardness value was varied from 31.7 to $245.3 \mathrm{~N}$ among different commercial gundpak samples (Table 4). There was a great variation in texture of the products. It might be due to varied composition, different degree of cooking, moisture content, and presence of fruit pieces in the product. Cohesiveness, gumminess, springiness, chewiness and adhesiveness values were varied from 90.03 to $296.3,7.84$ to $22.06 \mathrm{~N}, 2.36$ to $7.62 \mathrm{~mm}, 1.45$ to 16.2 N.mm, and 0.3 to $6.8 \mathrm{mNm}$, respectively, among the samples.

Table 4. Texture profiles of commercial samples of gundpak

\begin{tabular}{|c|c|c|c|c|c|c|}
\hline $\begin{array}{l}\text { Sample } \\
\text { code }\end{array}$ & $\begin{array}{l}\text { Hardness } \\
(\mathrm{N})\end{array}$ & $\begin{array}{c}\text { Cohesiveness } \\
(-)\end{array}$ & $\begin{array}{l}\text { Gumminess } \\
(\mathrm{N})\end{array}$ & $\begin{array}{l}\text { Springiness } \\
\quad(\mathrm{mm})\end{array}$ & $\begin{array}{l}\text { Chewiness } \\
\text { (N.mm) }\end{array}$ & $\begin{array}{l}\text { Adhesiveness } \\
\quad(\mathrm{mNm})\end{array}$ \\
\hline A & $245.3^{\mathrm{a}} \pm 4.4$ & $0.09^{\mathrm{a}} \pm 0.00$ & $22.1^{\mathrm{a}} \pm 0.65$ & $3.0^{\mathrm{b}} \pm 0.72$ & $6.9^{\mathrm{h}} \pm 1.81$ & $4.6^{\mathrm{g}} \pm 0.0$ \\
\hline B & $116.7^{\mathrm{b}} \pm 5.0$ & $0.13^{\mathrm{b}} \pm 0.02$ & $14.0^{\mathrm{b}} \pm 0.85$ & $4.2^{c} \pm 3.85$ & $2.8^{\mathrm{a}} \pm 0.28$ & $5.2^{\mathrm{f}} \pm 0.0$ \\
\hline $\mathrm{C}$ & $88.1^{\mathrm{c}} \pm 2.5$ & $0.14^{\mathrm{c}} \pm 0.01$ & $10.4^{\mathrm{cde}} \pm 0.76$ & $2.4^{\mathrm{a}} \pm 2.62$ & $1.4^{\mathrm{d}} \pm 0.23$ & $0.5^{\mathrm{a}} \pm 0.0$ \\
\hline D & $73.8^{\mathrm{d}} \pm 5.4$ & $0.16^{\mathrm{d}} \pm 0.01$ & $10.2^{\mathrm{cd}} \pm 1.0$ & $5.7^{\mathrm{d}} \pm 1.65$ & $6.1^{\mathrm{g}} \pm 0.67$ & $0.3^{\mathrm{b}} \pm 0.0$ \\
\hline $\mathrm{E}$ & $215.3^{\mathrm{e}} \pm 9.5$ & $0.07^{\mathrm{a}} \pm 0.01$ & $10.7^{\mathrm{ce}} \pm 3.01$ & $2.4^{\mathrm{a}} \pm 1.49$ & $2.7^{\mathrm{a}} \pm 0.48$ & $0.5^{\mathrm{a}} \pm 0.0$ \\
\hline $\mathrm{F}$ & $71.4^{\mathrm{f}} \pm 7.9$ & $0.14^{\mathrm{c}} \pm 0.03$ & $9.8^{\mathrm{f}} \pm 1.42$ & $3.0^{\mathrm{b}} \pm 0.80$ & $3.7^{\mathrm{b}} \pm 0.30$ & $2.0 \pm 0.0$ \\
\hline G & $89.7^{\mathrm{c}} \pm 2.4$ & $0.20^{\mathrm{g}} \pm 0.01$ & $18.5^{\mathrm{g}} \pm 0.21$ & $7.6^{\mathrm{g}^{\mathrm{g}}} \pm 1.81$ & $14.4^{\mathrm{c}} \pm 1.51$ & $6.4^{\mathrm{e}} \pm 0.0$ \\
\hline $\mathrm{H}$ & $31.7^{\mathrm{h}} \pm 2.4$ & $0.27^{\mathrm{h}} \pm 0.03$ & $7.8^{\mathrm{h}} \pm 0.8$ & $6.2^{\mathrm{e}} \pm 1.5$ & $4.0^{\mathrm{b}} \pm 0.01$ & $6.8^{\mathrm{e}} \pm 0.0$ \\
\hline I & $241.4^{\mathrm{a}} \pm 14.9$ & $0.13^{\mathrm{b}} \pm 0.04$ & $28.5^{\mathrm{i}} \pm 3.7$ & $5.0^{\mathrm{f}} \pm 0.4$ & $16.2^{\mathrm{f}} \pm 1.1$ & $0.4^{\mathrm{a}} \pm 0.0$ \\
\hline $\mathrm{J}$ & $97.8^{\mathrm{i}} \pm 0.5$ & $0.14^{\mathrm{c}} \pm 0.00$ & $13.4^{\mathrm{j}} \pm 0.3$ & $4.3^{\mathrm{c}} \pm 3.1$ & $3.3^{\mathrm{d}} \pm 0.6$ & $1.0^{\mathrm{c}} \pm 0.00$ \\
\hline K & $111.8^{\mathrm{j}} \pm 5.5$ & $0.21^{\mathrm{g}} \pm 0.06$ & $21.2^{\mathrm{k}} \pm 4.5$ & $5.7^{\mathrm{d}} \pm 3.6$ & $14.8^{\mathrm{c}} \pm 0.6$ & $0.4^{\mathrm{a}} \pm 0.00$ \\
\hline $\mathrm{L}$ & $39.7^{\mathrm{k}} \pm 4.67$ & $0.30^{\mathrm{e}} \pm 0.11$ & $8.9^{1} \pm 4.06$ & $6.5^{\mathrm{e}} \pm 2.0$ & $7.8^{\mathrm{e}} \pm 0.7$ & $0.7^{\mathrm{d}} \pm 0.00$ \\
\hline
\end{tabular}

Values are the mean of four replications. Values having same superscript in a column did not differ significantly. $\mathrm{N}=$ Newton; $\mathrm{N} \cdot \mathrm{mm}=$ Newton millimeter.

Instron hardness, gumminess and chewiness were negatively correlated with moisture and fat contents but positively with protein, lactose, added carbohydrates, ash and calcium contents for both khoa and gulabjamun. 
Cohesiveness was moderately influenced by the compositional characteristics, while no correlation was found between composition and springiness for both the products. Significant interrelationships among hardness with cohesiveness, gumminess and chewiness were observed (Adhikari, 1994). Post-manufacturing holding of product at $30^{\circ} \mathrm{C}$ for $72 \mathrm{~h}$ also affects the texture profiles of khoa because of changes of physical status of the product constituents, whereas cohesiveness and springiness did not differ significantly (Garg, 1989). The reasons for these changes are the physical status of the product constituents like crystallization of lactose and sucrose, solidification of fat. The previous finding of the similar product partially support the result obtained in this study. This might be due to non-optimized product in the market place.

The commercial product gundpak was kept at deep frozen $\left(-10^{\circ} \mathrm{C}\right)$ and reforming into the circular shape after bringing to room temperature for texture measurement has slightly disturbed the set structure might be the reason for variations in texture in addition to variations in formulations and process of commercial samples.

The textural characteristics derive from various physico-chemical properties of the food such as overall size and shape, particle size, fat content, structure and mechanical properties. Therefore, texture (hardness) is the combination of physical and chemical properties of the foods (Lewis, 1987). From these results, it can be concluded that the commercial samples vary significantly in quantity and quality of ingredients and also vary in processing conditions as they showed significant differences in texture profiles.

\subsection{Sensory Analysis of Gundpak}

According to the sensory analyses, colour, graininess and hardness of the samples was vary from $4.5-12.2 ; 5.7$ 11.0 and $4.3-10.4$, respectively. Similarly, mouth feel, gumminess, chewiness, sweetness and overall sensory quality were vary from $5.7-11.5,3.8-11.2,5.0-11.7,7.8-10.5$ and 10-11.7, respectively. As observed in other physico-chemical properties, significant variations in most of the sensory attributes as well were observed among the different commercial samples (Table 5).

Table 5. Sensory quality of commercial samples of gundpak

\begin{tabular}{llllllllll}
\hline S.N. & Color & Grainy & Hardness & $\begin{array}{l}\text { Mouth } \\
\text { feel }\end{array}$ & Gumminess & Chewiness & Sweetness & Off-flavor & OSQ $^{*}$ \\
\hline 1 & $10.5^{\mathrm{d}}$ & $11.0^{\mathrm{d}}$ & $10.4^{\mathrm{b}}$ & $11.0^{\mathrm{bc}}$ & $4.2^{\mathrm{a}}$ & $11.7^{\mathrm{c}}$ & $8.8^{\mathrm{a}}$ & $1.2^{\mathrm{a}}$ & $10.0^{\mathrm{a}}$ \\
& \pm 1.05 & \pm 0.95 & \pm 0.49 & \pm 0.63 & \pm 0.98 & \pm 0.52 & \pm 0.75 & \pm 0.26 & \pm 1.67 \\
2 & $8.9^{\mathrm{c}}$ & $6.0^{\mathrm{b}}$ & $5.0^{\mathrm{a}}$ & $6.2^{\mathrm{a}}$ & $6.7^{\mathrm{d}}$ & $11.0^{\mathrm{bc}}$ & $9.0^{\mathrm{a}}$ & $1.0^{\mathrm{a}}$ & $11.2^{\mathrm{ab}}$ \\
& \pm 0.80 & \pm 0.89 & \pm 0.89 & \pm 0.98 & \pm 1.21 & \pm 0.63 & \pm 1.41 & \pm 0.32 & \pm 0.98 \\
3 & $10.8^{\mathrm{d}}$ & $10.4^{\mathrm{c}}$ & $10.5^{\mathrm{b}}$ & $10.5^{\mathrm{b}}$ & $5.3^{\mathrm{c}}$ & $11.5^{\mathrm{bc}}$ & $7.8^{\mathrm{a}}$ & $1.3^{\mathrm{ab}}$ & $10.0^{\mathrm{a}}$ \\
& \pm 1.17 & \pm 0.88 & \pm 0.84 & \pm 1.05 & \pm 0.52 & \pm 0.84 & \pm 0.98 & \pm 0.52 & \pm 0.63 \\
4 & $4.5^{\mathrm{a}}$ & $5.7^{\mathrm{a}}$ & $5.0^{\mathrm{a}}$ & $5.7^{\mathrm{a}}$ & $11.2^{\mathrm{e}}$ & $5.0^{\mathrm{a}}$ & $10.5^{\mathrm{b}}$ & $1.3^{\mathrm{ab}}$ & $11.3^{\mathrm{ab}}$ \\
& \pm 1.05 & \pm 0.63 & \pm 0.89 & \pm 0.52 & \pm 0.98 & \pm 1.26 & \pm 1.38 & \pm 0.52 & \pm 1.97 \\
5 & $12.2^{\mathrm{e}}$ & $9.8^{\mathrm{c}}$ & $9.8^{\mathrm{b}}$ & $10.7^{\mathrm{bc}}$ & $3.8^{\mathrm{a}}$ & $11.7^{\mathrm{c}}$ & $8.5^{\mathrm{a}}$ & $1.7^{\mathrm{b}}$ & $11.7^{\mathrm{b}}$ \\
& \pm 0.75 & \pm 1.17 & \pm 1.47 & \pm 0.82 & \pm 1.17 & \pm 0.52 & \pm 0.55 & \pm 0.61 & \pm 0.52 \\
6 & $7.5^{\mathrm{b}}$ & $8.0^{\mathrm{b}}$ & $4.3^{\mathrm{a}}$ & $11.5^{\mathrm{c}}$ & $6.0^{\mathrm{a}}$ & $10.7^{\mathrm{b}}$ & $10.3^{\mathrm{b}}$ & $1.0^{\mathrm{a}}$ & $11.5^{\mathrm{b}}$ \\
& \pm 1.05 & \pm 0.45 & \pm 0.52 & \pm 0.55 & \pm 1.10 & \pm 0.82 & \pm 1.21 & \pm 0.00 & \pm 0.55 \\
\hline
\end{tabular}

Values are the mean of 12 panelists. Mean values in a column with same superscript didn't differ significantly at $p>0.05$ by $L S D$. Values $\pm S D . * O Q=$ Overall sensory quality.

\subsection{Minerals in Gundpak}

The minerals calcium, magnesium, sodium, potassium, iron, zinc and copper were in the ranges from $390.7-527.15,25.56-40.43, \quad 188.86-215.93,282.0-378, \quad 0.41-0.52, \quad 1.31-2.58$ and $0.11-0.16 \mathrm{mg} / 100 \mathrm{~g}$, respectively, in the product (Table 6). All values were found to be less than the values obtained in khoa samples (Bhogra and Mathur, 1991), it might be due to high percentage of sugar in the product. 
Table 6. Mineral content in commercial gundpak samples $(\mathrm{mg} / 100 \mathrm{~g})$ as is basis

\begin{tabular}{llllllll}
\hline Sample & Calcium & Magnesium & Sodium & Potassium & Iron & Zinc & Cupper \\
\hline A & $404.7 \pm 1.53$ & $25.6 \pm 1.01$ & $215.6 \pm 1.66$ & $285.0 \pm 1.41$ & $0.52 \pm 0.0 .01$ & $1.3 \pm 0.013$ & $0.16 \pm 0.007$ \\
B & $390.7 \pm 0.18$ & $27.0 \pm 0.15$ & $197.5 \pm 1.08$ & $296.3 \pm 1.41$ & $0.46 \pm 0.01$ & $1.7 \pm 0.015$ & $0.12 \pm 0.007$ \\
C & $424.5 \pm 0.93$ & $28.1 \pm 0.14$ & $215.5 \pm 0.16$ & $280.0 \pm 2.83$ & $0.41 \pm 0.0 .02$ & $1.7 \pm 0.015$ & $0.11 \pm 0.014$ \\
D & $527.2 \pm 0.62$ & $26.1 \pm 0.32$ & $209.6 \pm 0.87$ & $378.0 \pm 1.12$ & $0.43 \pm 0.0 .02$ & $2.6 \pm 0.013$ & $0.14 \pm 0.014$ \\
E & $466.2 \pm 0.57$ & $40.2 \pm 0.15$ & $188.7 \pm 0.62$ & $350.7 \pm 2.12$ & $0.44 \pm 0.0 .01$ & $2.1 \pm 0.012$ & $0.16 \pm 0.014$ \\
\hline
\end{tabular}

Values are the mean of duplicates. Values $\pm S D$.

\section{Conclusion}

A wide variations in physico-chemical and sensory properties were observed among different commercial samples of gundpak, indicating a need for optimization of the product to obtain uniform quality. For the better quality, the ingredients, time and temperature for cooking need to be optimized. There was no growth of Staphylococci in the samples similarly no growth of coliforms except sample A. Most of the retailers sell their products in open trays, which might contaminate the product with the yeast and molds and bacteria. The growth of Coliforms showed un-hygienic conditions in the production and selling areas. Good manufacturing practices should be followed for the production and selling of the product. Hygienic handling, packaging of products in compatible packaging materials and maintaining the cold chain in transportation and retail stores need to be maintained. The hardness, cohesiveness, gumminess, springiness, chewiness and adhesiveness values in the commercial gundpak samples were varied. The appearance and texture varied significantly in different commercial samples, the latter is due to variations in moisture, fat, protein content in the product. The overall sensory quality of the product did not vary significantly among the products.

\section{Acknowledgements}

The author's sincere thanks go to DFTQC for providing the laboratory facilities to carry out the proximate composition of the commercial samples. Thanks are also goes to Himalayan White House College for providing the facilities for microbial examination of the samples. The first author is grateful to Directors of CFTRI, CSIR, India and University Grant Commission, Nepal, who provide the scholarship to carry out the research work at CFTRI Research Laboratory. Thanks to Dr. B R Lokesh, Head, and S Yella Reddy, Senior Scientist, LSTF Department for facilitating the laboratory in research work. Thanks go to Institute of Science and Technology, Central Department of Food Technology, Dharan, Nepal, for providing me the opportunity to do this work.

\section{References}

Acharya, P. P., \& Sapkota, P. (2008). Effect of Processing Temperature and Ingredients in the Preparation of Gundpak - A Khoa Based Dairy Product. Nepal J. Sci. \& Technol., 9, 57-64.

Acharya, P. P., Kharel, G. P., \& Bhandari, M. R. (2011). Survey on production, marketing and consumption of Gundpak- a traditional khoa based sweet of Nepal. J. Food Sci. Technol. NEFOSTA, 6, 43-52.

Adhikari, A. K., Mathur O. N., \& Patil, G. R. (1994). Interrelationships among Textural Parameters, Composition and Microstructure of Khoa and Gulabjamun Made from Buffalo Milk. J Food Sci. Technol., 31(4), 279-284.

American Public Health Association (APHA). (2001). Compendium of Methods for the Microbiological Examination of Foods (Vol. 4, pp. 483-493). Washington, DC: American Public Health Associations.

Aneja, R. P., Mathur, B. N., Chandan, R. C., \& Banerjee, A. K. (2002). Technology of Indian Milk Products. Handbook on Process Technology Modernization for Professionals, Entrepreneurs and Scientists (pp. 81-87). Delhi, India: A Dairy India Publication.

AOAC. (2005). Official methods of analysis (11 ed.). Association of Official Analytical Chemists, Washington DC.

BIS. (1988). ISI Handbook of Food Analysis. General Methods, Part I, pp. 8-36.

Bhogra, V. R., \& Mathur, O. N. (1991). Chemical Quality of some marketed indigenous milk products. II. Mineral Composition of khoa. J. Fd. Sci. Technol., 28(1), 59-60. 
Bourne, M. C. (1978). Food Technol., 32(7), 62.

Chatterjee, T. K., Sarkar, S., \& Biswas, G. (1994). Quality Characteristics of Some Marketed Indigenous Milk Products: Major Constituents and Mineral Composition of Rabri. J. Food Sci. Technol, 31(5), 426-427.

Clydesdale, F. M. (1984). The influence of color on sensory perception and food choices. In J. Alford (Ed.) Development in Food Colors-2 (pp. 75-112). Elsevier Applied Science Publishers.

Dharayia, C. N., Rekha, R., \& Pagote, C. N. (2010). Basundi in Banglore City: A market survey. Indian Food Industry, 29(6), 22-28.

Ducan, D. B. (1955). Biometrics, 11, 1-42. http://dx.doi.org/10.2307/3001478

Dwarikanath, C. T., \& Srikanta, S. (1977). Studies on the Microbiological Quality of Traditional Indian Sweetmeat Products, J Fd. Sci. Technol., 1, 201-204.

Garg, F. C., Patel, A., Patil, G. R., Rajorhia, G. S., \& Gupta, S. K. (1989). Textural changes in Khoa during holding, Indian J Dairy Sci., 42(4).

Lewis, M. J., \& Hoewood, E. (1987). Physical Properties of Food Processing Systems. Solid Rheology and Texture, 137.

Nawajeevan, B., \& Rao, J. K . (2005). Physicochemical Changes in Retort Processed Kunda. Indian J dairy Sci, 58(6), 392-399.

Perez-Maganio, S., \& Gonzalez-Sanjose, M. L. (1999). Colorometric study of rose and red Spanish wines: Correlation between enological colour and CIELAB parameters. In M. I. Minguez, M. Jaren \& D. Hornero (Eds.), International Congress on pigments in Food Technology (pp. 423-427).

Ray, P. R., Bandopadhyay, A. K., \& Ghatak, P. K. (2002). Comparative studies on Quality of Market Available and Laboratory Made Peda. Indian J Dairy Sci., 83-85.

Sharma, D. K., \& Joshi, D. V. (1992). Bacteriological quality of milk and milk products with special reference to salmonella and its public health significance. J. Fd. Sci. Technol, 29(2), 105-107.

Sharma, U. P., \& Zariwala, I. T. (1978). Survey of Quality of Milk-Products in Bombay. J Fd Sci. Technol., 15, 118-121.

Suresh, I., \& Jha, Y. K. (1994). Optimization of the process for kalakand manufacturing and extension of its shelf life. J. Fd. Sci. Technol., 195, 389-394.

Thakur, B. N., Acharya, R. C., \& Shrestha, K. G. (1991). Indigenous Dairy Products of Nepal. Indian Dairyman, $\operatorname{XLIII}(3), 133-136$.

\section{Copyrights}

Copyright for this article is retained by the author(s), with first publication rights granted to the journal.

This is an open-access article distributed under the terms and conditions of the Creative Commons Attribution license (http://creativecommons.org/licenses/by/3.0/). 